\title{
FREQUENCY OF EPILOIA IN NORTHERN IRELAND
}

\author{
BY \\ A. C. STEVENSON AND O. D. FISHER, \\ Department of Social and Preventive Medicine Department of Child Health, Queen's University of Belfast
}

In the past five years a strenuous attempt has been made to ascertain all the cases of epiloia' in Northern Ireland. The Special Care Service (responsible for all aspects of mental deficiency and maintaining a central registry), the mental hospitals, children's hospitals, neurologists, paediatricians, and dermatologists have all co-operated in finding cases and all suspected cases have been reviewed.

We finally ascertained nine living cases (three males and six females) in eight families. None of the thirteen living parents, who were all examined, show any signs of the trait, and none of the parents are known to be related in any way. All but four of the 29 brothers and sisters of the affected subjects were seen, but it was possible to see only a small proportion of the sibs of the parents, because of deaths and movements overseas or because the parents were not willing for their sibs to be visited. The numbers seen are indicated in brackets in Table II. No history was obtained of major skin stigmata and their occupations do not suggest mental defect. Seven of the cases are single sporadic cases, but in the eighth family there is one definite case and one highly suspicious case which we feel should be regarded as affected although the diagnosis may not be certain for a number of years because the only symptoms so far noted are epileptiform convulsions. The essential clinical features of these cases are set out in Table I.

It will be seen that all for whom we have a reasonable history started with convulsions in infancy or early childhood and that the cutaneous signs which clinched the diagnosis came on in childhood. In family E.7 our information is incomplete, as the patient has been in a mental hospital for many years and has no living relatives, and the original clinical notes are scanty. A neighbour who knew her parents and a surviving step-father do not know of any dullness or skin signs in the parents.

In family E.8 the male propositus was recognized in the Royal Belfast Hospital for Sick Children when his epileptiform convulsions were being investigated. The small sister, who has fits, has as yet no cutaneous stigmata but is provisionally accepted as being affected. The affected girl in family E.6 is one of some interest, in that in spite of having typical

TABLE I

CLINICAL FEATURES OF CASES ASCERTAINED

\begin{tabular}{|c|c|c|c|c|c|}
\hline $\begin{array}{c}\text { Family } \\
\text { No. }\end{array}$ & $\begin{array}{l}\text { Age at } \\
\text { Onset }\end{array}$ & $\begin{array}{l}\text { Mode of } \\
\text { Onset }\end{array}$ & Sex & Signs, Symptoms, and Progress & Intelligence \\
\hline E 1 & 6 weeks & Convulsions & $\mathbf{F}$ & Adenoma sebacum, mild epileptic fits, patches of leucodermia & Imbecile \\
\hline E 2 & 5 weeks & Convulsions & $\mathbf{F}$ & $\begin{array}{l}\text { Adenoma sebacum, major epileptic fits, small telangiectatic spots on } \\
\text { trunk }\end{array}$ & Feeble-minded \\
\hline E 3 & 4 years & Convulsions & $\mathbf{M}$ & Adenoma sebacum, severe fits & I.Q. 65 \\
\hline E 4 & 11 months & Convulsions & $\mathbf{M}$ & $\begin{array}{l}\text { Adenoma sebacum, moderate fits, patches of leucodermia, severe telan- } \\
\text { giectasis on face }\end{array}$ & Low-grade imbecile \\
\hline E 5 & 12 weeks & Convulsions & $\mathbf{F}$ & Adenoma sebacum, moderate fits, red blotches on skin, enlarged thyroid & High-grade imbecile \\
\hline E 6 & 6 months & Convulsions & $\mathbf{F}$ & $\begin{array}{l}\text { Adenoma sebacum, raised leucodermic patches on flanks, mild epilepti- } \\
\text { form fits, petit mal }\end{array}$ & $\begin{array}{l}\text { Normal intelligence } \\
\text { (I.Q. 108) }\end{array}$ \\
\hline E 7 & Not known & Not known & $\mathbf{F}$ & Adenoma sebacum, telangiectasis, no convulsions, gross obesity & Imbecile \\
\hline \multirow[t]{2}{*}{ E 8} & 4 months & Convulsions & $\mathbf{M}$ & $\begin{array}{l}\text { Adenoma sebacum, convulsions, whitish perle patches on skin, well- } \\
\text { marked phakoma on each fundus with gliomatous nodular outgrowth } \\
\text { from optic nerves, possibly some early cystic change in parietal region } \\
\text { of skull }\end{array}$ & $\begin{array}{l}\text { Retarded to un- } \\
\text { known degree }\end{array}$ \\
\hline & 6 months & Convulsions & $\mathbf{F}$ & Convulsions only & Not known \\
\hline
\end{tabular}


convulsions and skin lesions she is of normal intelligence and passed her qualifying examination at age 11 .

Table II sets out the genetical data relevant to the families. The ages of the parents in E.7 are approximate and are as given by the surviving step-father of the subject. The parents of the affected subjects are not known to be related to one another.

The data are too few to form any conclusions about parental age, although the mean paternal age $(34 \cdot 3 \mathrm{yrs})$ and maternal age $(32 \cdot 1 \mathrm{yrs})$ of the seven sporadic cases seem high. Any ascertainment must be incomplete and any estimates made of gene frequency and mutation rates must be minimal for the following reasons:

(1) Mild cases, which are sporadic or represent the only living cases in the present generation, are impossible to ascertain. (Possible cases from the records of the dermatological clinics have been followed up, but many may not attend such clinics).

(2) Among the known cases of epilepsy in young children there may be at any given time children who will recognized until that time. recognized from time to time at post-mortem examinations in subjects who could not have been identified during life. subsequently develop skin stigmata but who cannot be

(3) It is well known that typical tuberose sclerosis is

(4) Most severely affected epiloics die relatively young; E.7-aged 40 years when seen-is an exception.

As Penrose (1949) has pointed out, many families with normal parents and more than one affected child have been described, and in some of these, parents have been related. The possibility that there is a recessive gene or alternative allele which can cause the condition cannot therefore be excluded.

It would seem that the number of cases is so small and the proportion of the genotypes ascertained so problematical as to make an estimation of mutation rates from these scanty data almost impossible. The justification for recording them is that there appears to have been no previous complete ascertainment of all the cases in a community.

The estimated population of Northern Ireland at the present time is $1,387,000$, so that the ascertained case frequency is about $1 / 150,000$.

We are indebted to the Medical Superintendents of the Mental Hospitals in Northern Ireland and to Dr. T. W. H. Weir, of the Special Care Service for much help in ascertaining cases.

REFERENCE

Penrose, L. S. (1949). "The Biology of Mental Defect." Sidgwick and Jackson, London.

TABLE II

DATA OF GENETICAL INTEREST RELATING TO AFFECTED SUBJECTS*

\begin{tabular}{|c|c|c|c|c|c|c|c|c|c|c|c|c|c|c|}
\hline \multirow[t]{2}{*}{$\begin{array}{l}\text { Family } \\
\text { No. }\end{array}$} & \multicolumn{3}{|c|}{ Affected Subject } & \multicolumn{3}{|c|}{ Number of Unaffected Sibs } & \multicolumn{3}{|c|}{ Sibs of Father } & \multicolumn{3}{|c|}{ Sibs of Mother } & \multicolumn{2}{|c|}{$\begin{array}{c}\text { Ages of Parents } \\
\text { when Affected } \\
\text { Subject was } \\
\text { Born (yrs) }\end{array}$} \\
\hline & $\begin{array}{l}\text { Age when } \\
\text { Seen }\end{array}$ & Sex & $\begin{array}{l}\text { Birth } \\
\text { Rank }\end{array}$ & Males & Females & $\begin{array}{c}\text { Mis- } \\
\text { carriages }\end{array}$ & Males & Females & Total & Males & Females & Total & Father & Mother \\
\hline E 1 & 20 & $\mathbf{F}$ & 1 & 一 & $2(2)$ & - & 1 & $1(1)$ & 2 & 4 & $4(2)$ & 8 & 26 & 31 \\
\hline E 2 & 24 & $\mathbf{F}$ & 1 & $3(1)$ & $2(2)$ & 一 & - & 一 & 一 & 1 & 7 (2) & 8 & 21 & 21 \\
\hline E 3 & 20 & $\mathbf{M}$ & 6 & 一 & $3(3)$ & 2 & 2 & 3 & 5 & $6(1)$ & $6(3)$ & 12 & 42 & 40 \\
\hline E 4 & 18 & $\mathbf{M}$ & 2 & $6(5)$ & $4(4)$ & - & 3 & $3(1)$ & 6 & $2(1)$ & $2(2)$ & 4 & 29 & 27 \\
\hline E 5 & 18 & $\mathbf{F}$ & 2 & $2(1)$ & - & - & - & 3 & 3 & - & 4 & 4 & 35 & 30 \\
\hline E 6 & 12 & $\mathbf{F}$ & 1 & - & $2(2)$ & - & $6(1)$ & $1(1)$ & 7 & 6 & $3(1)$ & 9 & 43 & 40 \\
\hline E 7 & 40 & $\mathbf{F}$ & 1 & - & - & - & $?$ & $?$ & $?$ & $?$ & $?$ & $?$ & 44 & 36 \\
\hline E 8 & $\begin{array}{l}6 \\
1\end{array}$ & $\underset{\mathbf{F}}{\mathbf{M}}$ & $\begin{array}{l}3 \\
8\end{array}$ & \}- & $5(5)$ & 1 & 3 & $1(1)$ & 4 & $2(1)$ & $2(1)$ & 4\{ & $\begin{array}{l}32 \\
38\end{array}$ & $\begin{array}{l}27 \\
33\end{array}$ \\
\hline
\end{tabular}

